\title{
Influence of VFR Tourism on the Quality of Life of the Resident Population
}

\author{
Alfonso González Damián \\ University of Quintana Roo, Cozumel México \\ Alma Rosa Macías Ramírez \\ University of Quintana Roo, Cozumel México
}

Received: 13 March 2020. Revision received: 24 April 2020. Accepted: 27 April 2020

\begin{abstract}
The aim of this document is to report on characteristics of VFR travel, the perceived impacts of these trips, and their effects on the quality of life of the resident community. Cozumel, an international insular tourist destination in Mexico, is taken as case of study. Data were obtained from a cross-sectional observational study, driven by survey conducted in Cozumel to characterize VFR trips, using an instrument that has been previously tested in other destinations and a composite scale was constructed to measure perceived quality of life by means of a survey administered to a sample of Cozumel residents. Structural equation models were used to test the influence of the social impacts perceived by the population on their quality of life. The movement of VFR travellers to Cozumel is significant, although their main expenses are not used in commercial accommodation. Community and economic impacts are perceived as significant by the population, whereas the impact on mobility and local transportation is perceived as negative. The direct and positive influence of economic benefits on the quality of life of local population was significant, whereas community-related and transportation-related impacts were significant only for residents who were not visited by friends or relatives. The main implications of these findings lead to the need to examine, in greater detail, the quality of life of residents in tourism destinations receiving VFR travelers. Thus, the main contribution of this paper, is to figure out that it is not the same to receive visitors than to observe others receiving them, not just in economic terms, but in terms of emotional and community well-being. This contrast is very likely to be confirmed in studies carried out in other international tourism destinations around the world.
\end{abstract}

Key Words: visits to family and friends, Impacts of tourism, quality of life, Cozumel, structural equation modelling.

JEL Classification: L83, Z32, D63.

Reference: González Damián, A., Macías Ramírez, A.R. (2020). Influence of VFR Tourism on the Quality of Life of the Resident Population. Journal of Tourism and Services, 20(11), 60-73. doi: 10.29036/jots.v11i20.142

\section{Introduction}

Trips to visit relatives and friends (VFR) represent an important segment of the international touristic industry, and the World Tourism Organization has indicated that around $11 \%$ of international trips are taken with the purpose of visiting family or friends (World Tourism Organization, 2016). In the case of Mexico, the Secretariat of Tourism reports that this type of trip represents close to $35 \%$ of trips taken by Mexican families (Secretariat of Tourism, 2013a) and is also the main reason for $28 \%$ of the trips taken by visitors from abroad (Secretariat of Tourism, 2013b), mainly by Mexican immigrants or Mexican descendants. 


\section{JOURNAL OF TOURISM AND SERVICES}

Issue 20, volume 11, ISSN 1804-5650 (Online)

www.jots.cz

The largest proportion (nearly 33\%) of total international visitors to Mexico are attracted by tourist destinations on the north coast of the state of Quintana Roo; among these is the island of Cozumel, where a flow of visitors rely on their family or friends for their trip. Visitors come both to consolidate family and friendship relationships and to enjoy an internationally attractive touristic option, which in 2012 amounted to over two million visits (Calculated based on data from the Secretariat of Tourism (SEDETUR, 2015)). In the same year, 140 thousand visitors were expected to visit relatives and friends in Cozumel.

VFR travel has been discussed by tourism academics since the 1980s, especially in regard to its accurate quantification, since travellers often fail to report that visiting relatives or friends is the main reason for their trip and indicate that their purpose is leisure, even when they intend to stay in the homes of friends or relatives and be provided other services by their hosts (Backer, 2008; Jackson, 1990). More recently, the discussion has focused on the analysis of the economic, sociocultural, and even environmental impacts associated with these types of trips, which are assumed to be of a different nature and to have a different structure in comparison with conventional trips, since there is a higher connection between the traveller and the visited site (Griffin, 2012).

Different authors have stressed the need to increase our knowledge and understanding of the ways in which VFR travel has a direct or indirect (Asiedu, 2008) or favourable or unfavourable (Belisle \& Hoy, 1980; Perdue, Long \& Allen, 1990) influence on the quality of life of the resident population (Liang \& Hui, 2016; Ziakas \& Costa, 2010) as a central indicator of the social sustainability of a tourist destination (Kim, Uysal, \& Sirgy, 2013; Macbeth, Carson, \& Northcote, 2004). In this regard, the present study analyzes the influence of VFR travel on the quality of life perceived by residents of Cozumel, a sun and beach destination, using a quantitative approach. The present paper begins by describing the theoretical basis of the study; its methodology and most remarkable findings are presented and discussed in ensuing sections, and our conclusions include reflections derived from the study.

\section{Literature review}

Although the economic impact of VFR travel, as well as tohurism in general (Gozgor \& Demir, 2018), has been a subject of analysis and debate in academia since the late 1980s, (Jackson, 1990), its social impact has been recently highlighted (Havitz, 2007; Larsen, Urry, \& Axhausen, 2007). From the point of view of social interchange, RFTs have an impact on the lives of both the traveller and the host (Gössling, Hall, \& Scott, 2015; Jackson, 2008); these visits have the function of confirming, reestablishing, reaffirming, consolidating, or deepening the value of social bonds with friends and relatives. It is with these intentions that people choose to travel, investing resources and time to visit relatives and friends who live in places away from their current residence, and that is also what motivates the willingness of visitors to act as hosts, providing resources, space, and time to their visitors (Backer, 2008; Shani \& Uriely, 2012).

However, not all VFR trips are taken for the sole purpose of visiting relatives or friends, but also for leisure (Jackson, 1990). Visitors choose a tourist destination where they incidentally visit relatives or friends with the implicit or explicit intention of using the host's resources for their benefit to save on their trip. Therefore, strengthening friendship and family ties is not the only motivation. In practice, there are three forms of VRF (Backer, 2012), one of them totally pure and two impure, in which the social impacts on the resident community may or may not be perceived as positive (Shani \& Uriely, 2012; Larsen, Urry, \& Axhausen, 2007). Regardless of whether or not visitors use accommodation services, with the impact that this also implies for the hotel industry, considered the axis of competitiveness of a tourist destination (Attila, 2016).

Perceived impacts of tourism, in general, have been analysed based mainly on the basis of social exchange theory, and they have been an issue of academic interest for decades. Although the theme has not been exhausted because contextual specificities and the effects of different variables are still 


\section{JOURNAL OF TOURISM AND SERVICES}

Issue 20, volume 11, ISSN 1804-5650 (Online)

www.jots.cz

unknown, composite scales to measure these indicators have been developed. Examples of these scales, based on the theory of latent variables (Bollen, 1989), have been applied to the impact of tourism on cultural and sporting events (Gursoy \& Kendall, 2006; Gursoy, Kim, \& Uysal, 2004; Kim, Gursoy, \& Lee, 2006; Yolal, Gursoy, Uysal, Kim, \& Karacaoğlu, 2016), sun and beach tourism (Fotsch, 2004; Gursoy \& Rutherford, 2004; Nunkoo \& Gursoy, 2012; Royle, 2009), cruise tourism (Brida \& Zapata, 2010; Seidl, Guillano, \& Pratt, 2006) community empowerment (Ranasinghe, \& Pradeepamali, 2019) and sustainable development (Eslami, et al., 2018). The development of these scales has stirred debates about the need to differentiate positive from negative social impacts (Kim, 2002; Kim, Jun, Walker, \& Drane, 2015; Yolal, Gursoy, Uysal, Kim \& Karacaoğlu, 2016), the need to measure social impacts as a second-order reflective latent variable (Gursoy \& Kendall, 2006), or as a formative latent variable based on a set of first-order reflective latent variables (Kim, 2002; Jani, 2019). Even though a general consensus based on convincing evidence has not been reached, the existence of different scales and measurement methods allows for the study of the social impacts of VFR travel on touristic sites and on the perception of their residents, whether or not they play the role of hosts for relatives or friends.

Quality of life as subjectively perceived by a community is a fundamental indicator of socially sustainable development, especially in the case of tourism, where the host society serves the visitors; from a social exchange perspective, the host society will be willing to share its resources as long as the impact of the visits is considered as relatively positive or favourable (González \& López, 2017). In this regard, research (Harrill, 2004; Marušić, Horak \& Tomljenović, 2008) has shown that residents of a touristic destination are willing to maintain a low quality of life and continue to receive visitors provided they receive economic benefits.

Perceived quality of life is associated with the level of satisfaction that the inhabitants of a community have with respect to different indicators of health, housing, and material circumstances as a reflection of overall satisfaction with their own lives, similarly than quality service assessment (Ahmed, et al., 2020; Bačík, et al., 2019; Chetthamrongchai \& Saengchai, 2019; Tovmasyan, 2020; Vergara \& Maza, 2018). Different scales have also been developed to measure quality of life as a latent formative variable based on a set of formative latent variables, all of them first-order (Kim, 2002), and there is an international consensus about the usefulness of this approach to measurement (Land, Michalos \& Sirgy, 2011; Nováková \& Šoltés, 2016; Nowak, 2018). These instruments have been used in the field of tourism studies to analyse the quality of life perceived by residents of touristic communities (Sharpley, 2014), and specifically by tourism service providers who have direct contact with tourists (Kaplanidou, Karadakis, Gibson, Thapa, Walker, Geldenhuys \& Coetzee, 2013). The relationship between the perceived impacts of tourism and the quality of life perceived by the population has also been measured from the perspective of social exchange, which differentiates the different types of social impact according to their effects on each of the formative aspects of perceived quality of life (González \& Macías, 2019; Kim, 2002). Subjective quality of life is affected by the perceived social impacts of tourism in general; therefore, it provides a framework that allows for the assertion that VFR travel, considered as a form of tourism, has social impacts on the recipient community and its members' subjective perception of their quality of life. Community residents who are visited by family or friends and share their leisure in different ways during visits can be expected to perceive the impact differently from residents who are not visited by family or friends.

\section{Methods}

Based on previous statements, the hypothetical model shown in Figure 1 was formulated for empirical testing. The model was organized in eight structural hypotheses indicating formative relationships (regressions) between perceived social impacts and perceived quality of life, in addition to a general hypothesis about expected differences among resident populations depending on whether they are visited by family or friends. 


\section{JOURNAL OF TOURISM AND SERVICES}

Issue 20, volume 11, ISSN 1804-5650 (Online)

www.jots.cz

Perceived quality of life is conceived as a structural relationship between three reflective latent variables, which exert a formative influence on a fourth latent variable that is also reflective, in short, as the relationship between the people's perceptions of community, emotional, and health- and safetyrelated satisfaction with their lives (Kim, 2002). Additionally, the present study proposed the existence of a structural relationship between perceived impacts and quality of life using the following nine hypotheses:

H1: Community benefits perceived as a result of VFR travel have a direct and positive effect on community wellbeing \& H2: On the emotional well-being of the residents of the touristic destination.

H3: Economic benefits perceived as a result of VFR travel have a direct and positive effect on community wellbeing \& H4: On the emotional well-being of the residents of the touristic destination.

Tourism has the potential to provide benefits to the recipient community; on the one hand, economic benefits derived from the sources of income, opportunities for employment, and new businesses made possible only by the visitors, and on the other hand, the general vitalization of commerce and services at the tourist destination (Deery, Jago, \& Fredline, 2012). Additionally, the site's status as an attractive destination to foreigners can give local people a sense of pride because they are part of the community, due to the site's attractive characteristics, and because they share the cultural identity of the destination (Nunkoo \& Gursoy, 2012). When thus perceived, these benefits have effects on the wellbeing domains, that is, on the formative background of perceived quality of life. The domain of community well-being refers to the factors that determine an individual's perception that people who share their place of residence, as well as the facilities and spaces in which they live, contribute to their personal satisfaction (Sirgy \& Cornwell, 2001). For its part, the domain of emotional well-being refers to those factors that contribute to emotional satisfaction, such as the use of free time and leisure and cultural activities available in one's place of residence. Four hypotheses about the relationship between perceived benefits and both domains of quality of life are presented.

H5: The impact of VFR travel on mobility and traffic at the destination has a direct and negative effect on community well-being \& H6: On the emotional well-being of the residents of the touristic destination. However, in addition to benefits, tourism is perceived by the residents of a touristic destination to bring negative impacts in the economic, social, and cultural spheres (Uysal, Perdue \& Sirgy 2012). For instance, a study has reported on the negative impact of tourism on mobility and transportation for the destination's residents, whose transportation and communications systems are perceived as occupied by tourists; in this case, the negative effects of tourism are experienced at the personal level (Sirgy, Rahtz, Cicic \& Underwood, 2000). This is clearly are not the only possible case of negative impact that can and does occur, but the example is representative in that it is directly associated with the touristic season, and therefore, tourism is intrinsically associated with the disruption in the resident's imaginary (Yolal et al., 2016). Thus, the negative impacts affeconomics-czect both the community and the well-being domains, degrading the elements that determine quality of life, and consequently, decreasing the residents' satisfaction with their lives (Sirgy \& Cornwell, 2001).

H7: The well-being of the community of a touristic destination have a direct and positive influence on their satisfaction with life \& H8: The emotional well-being of the residents of a touristic destination have a direct and positive influence on their satisfaction with life.

Community well-being and emotional well-being are two of the multiple factors behind people's overall satisfaction with their quality of life in a touristic destination (Rakauskienè \& Volodzkienè, 2017; Woo, Kim, \& Uysal, 2015). The subjective evaluation of quality of life made by the residents is affected by their emotional well-being and by their community well-being. Higher well-being scores correspond to higher values in people's overall assessment of their quality of life (Yu, Cole, \& Chancellor, 2016).

Finally, we hypothesized that, when considered separately, certain differences would emerge between residents who are visited by family and friends and those who are not visited:

H9: There are structural differences reflected by the confirmation or lack of confirmation of the bypotheses for each group, as well as in the degree of influence between the variables of interest. This means that being visited or not being 


\section{JOURNAL OF TOURISM AND SERVICES}

Issue 20, volume 11, ISSN 1804-5650 (Online)

www.jots.cz

visited at home moderates the effect of perceived impacts on the residents' subjective quality of life. Being visited by relatives or friends has an unquestionable impact on the lives of the residents of a tourist destination; however, our literature review found no studies centred on the effect of this impact on people's subjective evaluation of their quality of life.

Graph 1. Hypothetical model of structural relationships between perceived impacts of VFR travel and subjective quality of and life of residents in touristic destinations

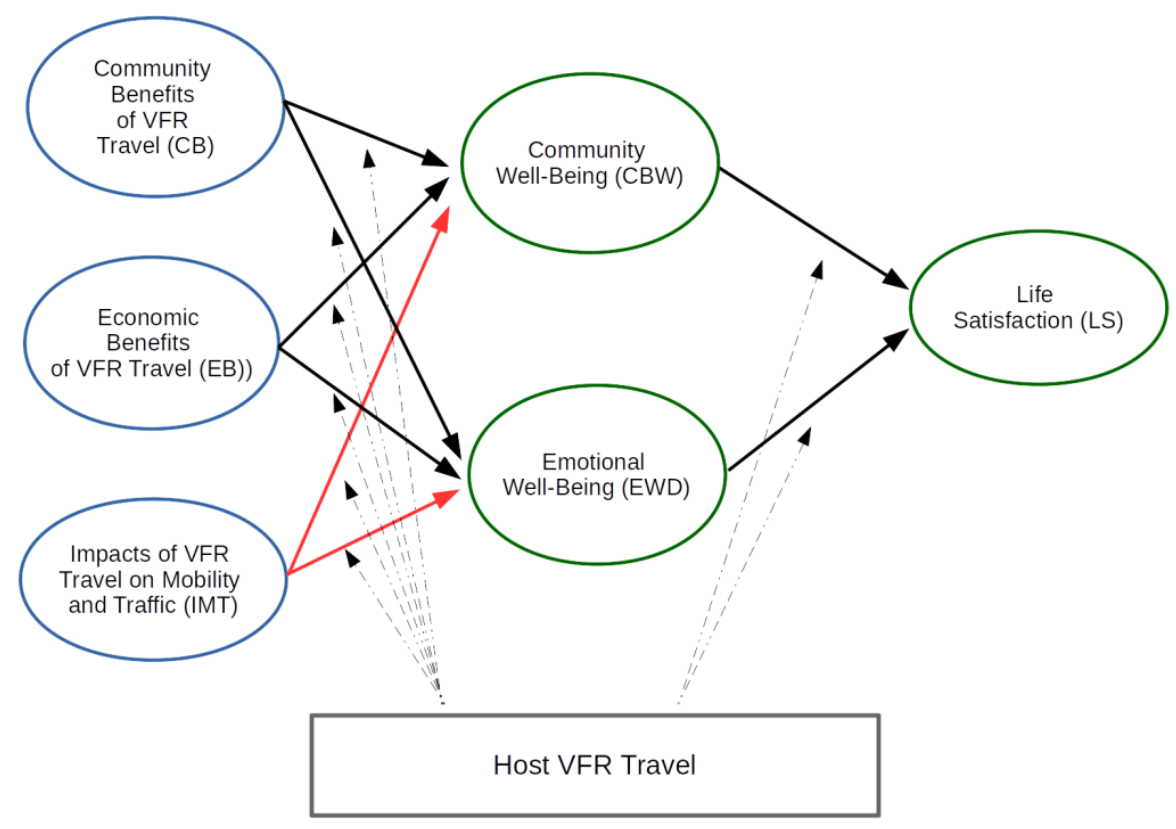

Source: Elaborated by the authors.

A cross-sectional, survey-based study was designed to test the hypothetical model per the following procedure:

1. A study area was defined: Cozumel island is well-known as a sun and beach touristic destination, and it is visited by approximately three million people per year (SEDETUR, 2015). Most of them are cruise passengers who visit the island for a day. Cozumel is the main destination for this type of visitor in Mexico. Its main attraction is its location in the Mesoamerican reef system, which makes it an ideal place to practice underwater activities, such as snorkelling and scuba diving. The city of San Miguel de Cozumel is equipped with communications infrastructure, an international airport, docks for international cruise liners, and a variety of lodging and food \& beverages services, in addition to water and land activities operators; these services are the main economic activity of the city's almost eighty thousand inhabitants.

Table 1. Latent variables comprised in the composite scale of perception of social impacts of VFR travel

\begin{tabular}{|l|l|l|}
\hline Variable & Item & Content \\
& & How much do you agree with the statement? \\
\hline Community Benefits (CB) & & Thanks to visits by family and friends... \\
\cline { 2 - 3 } & CB1 & Cozumel residents increased their pride in the community \\
\cline { 2 - 3 } & CB2 & Our sense of belonging in Cozumel increased \\
\hline
\end{tabular}




\section{JOURNAL OF TOURISM AND SERVICES}

Issue 20, volume 11, ISSN 1804-5650 (Online)

www.jots.cz

\begin{tabular}{|l|l|l|}
\hline \multirow{4}{*}{ Economic Benefits (EB) } & CB3 & The preservation of Cozumel's culture was encouraged \\
\cline { 2 - 3 } & CB4 & The spirit of Cozumel's community was strengthened \\
\hline \multirow{2}{*}{$\begin{array}{l}\text { Impacts on Mobility and Transportation } \\
\text { (IMT) }\end{array}$} & EB1 & Economic conditions improved \\
\cline { 2 - 3 } & EB2 & The number of entertainment facilities increased \\
\cline { 2 - 3 } & EB3 & Investment in community development increased \\
\cline { 2 - 3 } & IMT1 & As a consequence of visits by family and friends... \\
\cline { 2 - 3 } & IMT2 & Finding parking places was more difficult \\
\cline { 2 - 3 } & IMT3 & Increased difficulty to commute in the island \\
\hline \multirow{2}{*}{$\begin{array}{l}\text { * The wording of the items evaluating the social benefits variable was modified to obtain comparable responses in the } \\
\text { sample from those who were not visited by friends or relatives. }\end{array}$} \\
\hline
\end{tabular}

Source: Adapted from Kim and Uysal (2013), Gursoy, and Kendall (2006), and González and López (2017)

Given that the island is recognized as an important touristic destination, it receives a flow of national and international VFR travel, which makes it a relevant case to be used as an object of study to test the proposed hypothetical model.

2. A sample of 242 households in the city, determined by random cluster sampling, was administered a survey. The areas in which the questionnaire was administered were chosen randomly. The questionnaire was originally tested in other populations in the state of Quintana Roo (Sosa, Martínez, Moncada, Beltrán, \& Álvarez, 2015); its questions are aimed at characterizing the profile of the visitors if the respondent received any visits, as well as the respondents' sociodemographic profile. Two composite scales were included in the original questionnaire to measure a) the perceived impact of VFR travel (see Table 1) and b) the residents' perception of their quality of life (see Table 2). All items were rated by the respondents on a five-point Likert scale from 1 to 5.

3. The information obtained from the survey was analysed using $\mathrm{R}$ statistical programming software (R Core Team, 2018) lavaan (Rosseel, 2012), and semTools (Jorgensen, Pornprasertmanit, Schoemann \& Rosseel, 2019). The following analyses were carried out:

- Statistical description of visitor and respondent profiles.

- Confirmatory factor analysis (CFA) and analysis using structural equation models (SEM) to test the hypothetical model empirically.

Table 2. Structural measurement of perceived quality of life

\begin{tabular}{|l|l|l|}
\hline Variable & Item & Content \\
& & How satisfied do you feel about...? \\
\hline \multirow{4}{*}{$\begin{array}{l}\text { Community Well-being Domain (CWD)Title of the } \\
\text { paper }\end{array}$} & CWD1 & The facilities and services available in Cozumel \\
\cline { 2 - 3 } & CWD2 & The people who live in Cozumel \\
\cline { 2 - 3 } & CWD3 & The security in the streets of Cozumel \\
\hline \multirow{4}{*}{ Emotional Well-being Domain (EWD) } & EWD1 & Your free time \\
\cline { 2 - 3 } & EWD2 & The leisure activities that you do \\
\cline { 2 - 3 } & EWD3 & The cultural activities that you do \\
\hline \multirow{3}{*}{ Satisfaction with life (SV) } & LS1 & Your life as a whole (Your life in general) \\
\cline { 2 - 3 } & LS2 & The way in which you live your life \\
\cline { 2 - 3 } & LS3 & Your life compared with others' \\
\hline
\end{tabular}

Source: Adapted from Kim and Uysal (2013)

\section{Results}

\subsection{Descriptive results}




\section{JOURNAL OF TOURISM AND SERVICES}

Issue 20, volume 11, ISSN 1804-5650 (Online)

www.jots.cz

According to the results, $54.55 \%$ of households received at least one visit by family members or friends during the analysed period. A total of 598 people stayed in the households that were visited during the year, which represents almost 2.5 visitors per household. Considering that the total number of households in Cozumel is approximately 24,147 (INEGI, 2010), the total number of VFR trips can be expected to be almost 60 thousand during the year.

In view of these figures, and based on the data obtained by the survey, visitors spent an average of $\$ 7,582.40 \mathrm{MXN}$ per visit, and their hosts spent an average of $\$ 3,233.33 \mathrm{MXN}$ per household per visit; therefore, Cozumel's income derived from VFR travel represented approximately $\$ 376$ million Mexican pesos (close to 21 million USD) during the one-year period from 2015-2016.

The profile of VFR travel in Cozumel is as follows: $69.6 \%$ of the travellers were relatives of Cozumel residents; the average number of people per visit was 2.1; $97.66 \%$ of the visitors came from other parts of Mexico, most of them from Yucatan, the rest of Quintana Roo, and Mexico City; for 50\% of the travellers, the main reason for the trip was leisure, whereas in $41.43 \%$ of the cases the genuine reason was visiting family and friends; in average, visitors stayed for 6.4 nights in their hosts' homes and 0.91 nights in commercial lodging services and stayed an average of 3.75 nights in the island; the most frequent transportation method was by bus and by ship (48.91\%), followed by a flight to Cancún and a ship to Cozumel (23.6\%), and only $9.49 \%$ of the travellers flew to the island. Their main activities were visiting the beaches, performing water activities, going to natural parks, restaurants, bars, and clubs, as well as visiting other friends or relatives on the island. Some of the travellers $(18.9 \%)$ left the island to visit other places, mostly Playa del Carmen, Cancún, and Tulum, in descending order.

\subsection{Model contrast}

Conditions for the analysis of structural relationships between variables measured using composite scales were verified in order to apply the CFA. As a result, the reliability and validity of the constructs were corroborated with the synthetic data shown in Table 3.

Table 3. Results of Confirmatory Factor Analysis

\begin{tabular}{|c|c|c|c|c|c|}
\hline Variable & Item & $\alpha$ & $\omega$ & $\lambda$ & AVE \\
\hline \multirow[t]{4}{*}{$\mathrm{CB}$} & CB1 & \multirow[t]{4}{*}{0.828} & \multirow[t]{4}{*}{0.831} & $0.644^{*}$ & \multirow[t]{4}{*}{0.556} \\
\hline & $\mathrm{CB} 2$ & & & $0.762 *$ & \\
\hline & CB3 & & & $0.764 *$ & \\
\hline & CB4 & & & $0.791 *$ & \\
\hline \multirow[t]{3}{*}{ EB } & EB1 & \multirow[t]{3}{*}{0.823} & \multirow[t]{3}{*}{0.843} & $0.633^{*}$ & \multirow[t]{3}{*}{0.641} \\
\hline & EB2 & & & $0.875^{*}$ & \\
\hline & EB3 & & & $0.851 *$ & \\
\hline \multirow[t]{3}{*}{ IMT } & IMT1 & \multirow[t]{3}{*}{0.796} & \multirow[t]{3}{*}{0.8} & $0.683^{*}$ & \multirow[t]{3}{*}{0.577} \\
\hline & IMT2 & & & $0.825^{*}$ & \\
\hline & IMT3 & & & $0.753^{*}$ & \\
\hline \multirow[t]{3}{*}{ CWD } & CWD1 & \multirow[t]{3}{*}{0.671} & \multirow[t]{3}{*}{0.68} & $0.687 *$ & \multirow[t]{3}{*}{0.414} \\
\hline & CWD2 & & & $0.610^{*}$ & \\
\hline & CWD3 & & & $0.632 *$ & \\
\hline \multirow[t]{3}{*}{ EWD } & EWD1 & \multirow[t]{3}{*}{0.8} & \multirow[t]{3}{*}{0.812} & $0.703^{*}$ & \multirow[t]{3}{*}{0.589} \\
\hline & EWD2 & & & $0.828^{*}$ & \\
\hline & EWD3 & & & $0.760^{*}$ & \\
\hline \multirow[t]{3}{*}{ LS } & LS1 & \multirow[t]{3}{*}{0.805} & \multirow[t]{3}{*}{0.804} & $0.796^{*}$ & \multirow[t]{3}{*}{0.579} \\
\hline & LS2 & & & $0.796^{*}$ & \\
\hline & LS3 & & & $0.697 *$ & \\
\hline \multicolumn{6}{|c|}{ Goodness of fit indicators } \\
\hline \multicolumn{2}{|c|}{$\chi^{2}(137 \mathrm{gl})=209.830^{*}$} & NNFI & CFI & TLI & RMSEA \\
\hline
\end{tabular}


JOURNAL OF TOURISM AND SERVICES

Issue 20, volume 11, ISSN 1804-5650 (Online)

www.jots.cz

\begin{tabular}{|l|l|l|l|l|l|}
\hline & 0.915 & 0.946 & 0.932 & 0.933 & 0.047 \\
\hline$* \mathrm{p}<0.01$ &
\end{tabular}

Source: Elaborated by the authors.

SEM analysis was performed after confirming the validity of the measurement, fitting the model by groups depending on whether the respondent had hosted a VFR trip or not. Table 4 shows these results and indicates whether the hypotheses were accepted or not; result 1 refers to people who were visited by friends or relatives and result 2 to people who were not visited by friends or relatives.

Table 4. SEM results

\begin{tabular}{|c|c|c|c|c|c|c|}
\hline $\begin{array}{l}\text { Hypothes } \\
\text { is }\end{array}$ & \multicolumn{2}{|c|}{ Proposed structural relationship } & $\lambda 1$ & Group 1 & $\Lambda 2$ & Group 2 \\
\hline $\mathrm{H}_{1}$ & \multicolumn{2}{|c|}{$\mathrm{CB} \rightarrow \mathrm{CWD}$} & 0.027 & Rejected & $0.389 * *$ & Accepted \\
\hline $\mathrm{H}_{2}$ & \multicolumn{2}{|c|}{$\mathrm{CB} \rightarrow \mathrm{EWD}$} & -0.138 & Rejected & $0.569^{* *}$ & Accepted \\
\hline $\mathrm{H}_{3}$ & \multicolumn{2}{|c|}{$\mathrm{EB} \rightarrow \mathrm{CWD}$} & $0.526^{* *}$ & Accepted & $0.411 * *$ & Accepted \\
\hline $\mathrm{H}_{4}$ & \multicolumn{2}{|c|}{$\mathrm{EB} \rightarrow \mathrm{EWD}$} & $0.622^{* *}$ & Accepted & $0.348^{* *}$ & Accepted \\
\hline $\mathrm{H}_{5}$ & \multicolumn{2}{|c|}{$\mathrm{IMT} \rightarrow \mathrm{CWD}$} & -0.062 & Rejected & $-0.302 *$ & Accepted \\
\hline $\mathrm{H}_{6}$ & \multicolumn{2}{|c|}{ IMT $\rightarrow$ EWD } & -0.086 & Rejected & -0.132 & Rejected \\
\hline $\mathrm{H}_{7}$ & \multicolumn{2}{|c|}{$\mathrm{CWD} \rightarrow \mathrm{LS}$} & $0.447 * *$ & Accepted & $0.274 *$ & Accepted \\
\hline $\mathrm{H}_{8}$ & \multicolumn{2}{|c|}{$\begin{array}{c}\mathrm{EWD} \rightarrow \mathrm{LS} \\
\end{array}$} & 0.13 & Rejected & $0.482^{* *}$ & Accepted \\
\hline \multicolumn{7}{|c|}{$\begin{array}{l}\text { Model goodness of fit indicators3. The information obtained from the survey was analysed using } R \\
\text { statistical programming software (R Core Team, 2018) lavaan (Rosseel, 2012), and semTools (Jorgensen, } \\
\text { Pornprasertmanit, Schoemann \& Rosseel, 2019). The following analyses were carried out: } \\
\text { - Statistical description of visitor and respondent profiles. } \\
\text { - Confirmatory factor analysis (CFA) and analysis using structural equation models (SEM) to test the } \\
\text { hypothetical model empirically. }\end{array}$} \\
\hline \multicolumn{3}{|c|}{ Total } & \multicolumn{2}{|c|}{$\begin{array}{c}\text { Group } 1 \text { (Hosted VFR } \\
\text { travel) }\end{array}$} & \multicolumn{2}{|c|}{$\begin{array}{c}\text { Group } 2 \text { (Did not host } \\
\text { VFR travel) }\end{array}$} \\
\hline \multicolumn{2}{|c|}{$295 \mathrm{gl}$} & $\chi^{2}=501.627^{* *}$ & 139 Obs. & $\begin{array}{c}\chi^{2}=265.006^{*} \\
*\end{array}$ & 102 Obs. & $\begin{array}{c}\chi^{2}=236.621 * \\
*\end{array}$ \\
\hline \multicolumn{2}{|c|}{ NNFI } & CFI & IFI & TLI & RFI & RMSEA \\
\hline \multicolumn{2}{|c|}{0.873} & 0.891 & 0.893 & 0.873 & 0.739 & 0.077 \\
\hline
\end{tabular}

Source: Elaborated by the authors.

\section{Discussion}

The first aspect to be highlighted concerning the results of the present study is that the population of Cozumel recognizes that VFR travel can bring positive and negative social impacts, which means that the scale can be used as an indicator to measure the perception of these impacts as a latent variable that cannot be directly observed or measured. This result is consistent with studies carried out in other parts of the world (Backer, 2008, 2012; Shani \& Uriely, 2012), which confirms that the scale can be used to measure the effects of VFR travel on other variables, such as was done with quality of life in the present study.

Cozumel's residents have a subjective perception of their general quality of life as high, which could be surprising considering local poverty indices and the insufficient coverage of health care, education, and social support services in the city; these indicators are equivalent to the national average, ranked last in comparison with the rest of OECD member countries (2017). This means that, although the scale is reliable and presents internal validity, it is very probable that its interpretation would need to 


\section{JOURNAL OF TOURISM AND SERVICES}

Issue 20, volume 11, ISSN 1804-5650 (Online)

www.jots.cz

be mediated by some contextual factor, for instance, the perception that quality of life is worse in other parts of the country, or other indicators associated with local idiosyncrasies (O'Brien, 2008).

People who host VFR travel in Cozumel perceive the economic impact of tourism on the domains of emotional and community well-being; however, only the positive influence of community well-being influences their overall their satisfaction with life. These positive influences are more substantial than those perceived by the population who do not host VFR travel. The fact that five of the eight hypotheses were rejected indicates that the positive and negative impacts of VFR travel are not evaluated similarly by those who hosted, served, and shared these trips with the visitors than by those who were not visited. This suggests the presence of other intervening variables that obscure the results, such as the differences between being visited by family or by friends (Backer, Leisch \& Dolnicar, 2017), or the specific activities shared with the visitors during their stay, among other possibilities.

It is also worth noting that, although this group of residents perceives the positive community impacts of VFR travel in addition to its negative impacts, for example on mobility and traffic in the city, there is no statistically significant effect on the quality of life of the residents who were visited by friends or family, in other words, there are practically no perceptible changes in the lives of residents who are visited by family or friends due to the economic and community impacts derived from the visits.

On the other hand, Cozumel residents who were not visited by family or friends in their homes perceive significant effects of economic and community benefits on the emotional and community wellbeing domains, and consequently, on their overall satisfaction with life. This result could mean that residents who do not receive visitors, and therefore do not invest time or resources, would tend to think that VFR travel has positive economic and community effects on the quality of life of the general population in Cozumel, However, the fact that those who received visitors perceived the influence of the economic impacts of tourism on their emotional well-being and on community well-being with greater intensity is striking. These findings confirm what other studies (Uysal et al., 2012) have reported on the impacts of tourism on quality of life; therefore, for this group of residents, VFR travel is comparable to any other form of tourism.

It should be highlighted that one hypothesis was rejected for the group of residents who were not hosts to family or friends, namely, the relationship between negative impacts on mobility and transportation and emotional well-being. Concerning this relationship, which was found to be consistently significant in the literature (Gursoy, Kim, \& Uysal, 2004; Gursoy \& Kendall, 2006; Gursoy \& Rutherford, 2004), the case of Cozumel can be nuanced by a specific contextual condition that has to do with the type of tourism characteristic of the island, that is, passengers on cruise ships who visit the island from Monday to Saturday; thus, the city is free from the massive presence of tourists on Sundays, when the city's residents spend their free time on leisure and cultural activities.

In a more global interpretation, it could be stated that residents, as social actors playing the role of hosts, although they perceive a lower social impact from the visits, in order to maintain their strategic position in the context of relationships in this context, they themselves need to invest in the relationship, because indirectly they perceive a benefit at the local level, but also very likely in a future visit to their current visitors, which could be considered an additional positive impact. In turn, the members of the community who are not visited see this type of visit as another form of tourism, which brings more benefits than costs to society in Cozumel.

\section{Conclusion}

One of the oldest forms of tourism consists in visiting family and friends. It represents an important contribution to the total tourism market and has a high impact due to the intensity, duration, and repetition of the relationship between hosts and visitors. Despite that, this type of tourism has been given relatively little attention in academic studies, which began to focus on its quantification at the end 


\section{JOURNAL OF TOURISM AND SERVICES}

Issue 20, volume 11, ISSN 1804-5650 (Online)

www.jots.cz

of the twentieth century in order to measure its economic importance. These initial attempts encountered issues when outlining and formally monitoring the phenomenon. Since then, the need to analyse and evaluate its effects on the social fabric of tourist destinations receiving this type of visit has been highlighted, although there is still relatively scant scientific production in this regard. The present study sought to examine the relationship between the impacts of this form of tourism on the quality of life subjectively perceived by people who live in a tourist destination. The movement of VFR travellers to Cozumel is significant, although their main expenses are not used in commercial accommodation. Community and economic impacts are perceived as significant by the population, whereas the impact on mobility and local transportation is perceived as negative.

For that purpose, the present study used a cross-sectional method to analyse the case of Cozumel island, Mexico, whose results allowed for the comparison of the hypothetical model of the relationships between the impacts of VFR travel and the residents' subjective quality of life, which was validated for Cozumel residents who were not visited by family or friends in their homes. The study also validated the hypothesis that there are differences in the perceived impact on quality of life that depend on whether residents are visited by family and friends or not.

We also found a direct and positive influence of perceived economic benefits on the emotional and community well-being domains of local residents who were visited by family or friends to be significant; this was also found in the case of residents who were not visited, who also reported a positive and significant influence on their quality of life. Negative impacts on mobility and transportation were found to have a significant influence on the domain of community well-being in the group of people who were not visited by friends or relatives.

These findings highlight the main contribution of the present study toward a clear image of this phenomenon; in the case of Cozumel, the evidence shows that VFR travel has a direct impact on the quality of life of the residents in the surveyed areas, and the influence is clearly different when evaluated by residents who have been visited by family or friends in their homes. This observation is consistent with academic literature that has identified the perception of impact as mediated by the closeness of the interaction between residents and tourists (Woo, Uysal, \& Sirgy, 2016) and confirms the need to explore the social impact of VFR travel.

Our findings are restricted to the case of Cozumel, but they point to the need to analyse the relationships of these variables in other touristic sites, both cross-sectionally and longitudinally. The need to pay closer attention to the distinction between family visits and visits by friends, which were included in the same concept, is also clear, but the impact on the social fabric of the receiving communities requires a new perspective. In addition, the future direction of VFR research suggests the need to analyse the structural relationships of the impacts of this type of tourism with other social variables, such as social capital, resilience, or tolerance among the members of the host society, individuals, and groups, as well as the moderating influence of these structural relationships on the personal, contextual, and historical aspects of both visitors and hosts.

In the same vein, it is becoming clear that further study and detailed analysis of the social impact of VFR travel on the perceived quality of life in communities residing in touristic destinations is needed, as well as longitudinal comparisons and analyses to study its significance for the socially sustainable development of tourism.

\section{References}

1. Ahmed, R. R., Romeika, G., Kauliene, R., Streimikis, J., \& Dapkus, R. (2020). ES-QUAL model and customer satisfaction in online banking: evidence from multivariate analysis techniques. Oeconomia Copernicana, 11(1), 59-93. https://doi.org/10.24136/oc.2020.003 


\section{JOURNAL OF TOURISM AND SERVICES}

Issue 20, volume 11, ISSN 1804-5650 (Online)

www.jots.cz

2. Asiedu, A. B. (2008). Participants' characteristics and economic benefits of visiting friends and relatives (VFR) tourism - an international survey of the literature with implications for Ghana. International Journal of Tourism Research, 10(6), 609-621. http://doi.org/10.1002/jtr.698

3. Attila, A. T. (2016). The Impact of the Hotel Industry on the Competitiveness of Tourism Destinations in Hungary. Journal of Competitiveness, 8(4), 85-104. https://doi.org/10.7441/joc.2016.04.06

4. Backer, E. (2008). VFR Travellers - Visiting the Destination or Visiting the Hosts? Asian Journal of Tourism and Hospitality Research, 2(1), 60-70.

5. Backer, E. (2012). VFR travel: It is underestimated. Tourism Management, 33(1), 74-79. https://doi.org/10.1016/j.tourman.2011.01.027

6. Backer, E., Leisch, F., y Dolnicar, S. (2017). Visiting friends or relatives? Tourism Management, 60, 56-64. https://doi.org/10.1016/J.TOURMAN.2016.11.007

7. Bačík, R., Fedorko, R., Rigelský, M., Abbas, E. W., Ivanková, V., \& Obšatníková, K. (2019). The Impact of Selected Quality Management Attributes on the Profitability of TOP Hotels in the Visegrad Group Countries. Polish Journal of Management Studies, 19(1), 46-58. https://doi.org/10.17512/pjms.2019.19.1.04

8. Belisle, F. J., y Hoy, D. R. (1980). The perceived impact of tourism by residents a case study in Santa Marta, Colombia. Annals of Tourism Research, 7(1), 83-101. https://doi.org/10.1016/S01607383(80)80008-9

9. Bollen, K. A. (1989). Structural equations with latent variables. New York: John Wiley and Sons.

10. Brida, J., y Zapata, S. (2010). Cruise tourism: economic, socio-cultural and environmental impacts. International Journal of Leisure and Tourism, 1(2), 205-226.

11. Chetthamrongchai, P., \& Saengchai, S. (2019). The impact of perceived service quality, customer perception and price strategy on pharmacy customer devotion. Polish Journal of Management Studies, 20(1), 139-148. https://doi.org/10.17512/pjms.2019.20.1.12

12. Deery, M., Jago, L., y Fredline, L. (2012). Rethinking social impacts of tourism research: A new $\begin{array}{llll}\text { research } & \text { agenda. } & \text { Tourism } & \text { Management, }\end{array}$ https://doi.org/10.1016/j.tourman.2011.01.026

13. Eslami, S., Khalifah, Z., Mardani, A., \& Streimikiene, D. (2018). Impact of non-economic factors on residents' support for sustainable tourism development in Langkawi Island, Malaysia. Economics \& Sociology, 11(4), 181-197. https://doi.org/10.14254/2071-789X.2018/11-4/12

14. Fotsch, P. M. (2004). Tourism's uneven impact. Annals of Tourism Research, 31(4), 779-800. http://doi.org/10.1016/j.annals.2004.02.004

15. González, A., \& López, R. J. (2017). Evaluation of host community support for the staging of touristic cultural and sports events in small cities. Revista de Análisis Turístico, 23(1), 1-13. Retrieved from: https://aecit.org/jornal/index.php/AECIT/article/view/232/205

16. González, A., \& Macías, A. R. (2019). Influencia del capital social en la calidad de vida de los habitantes de la isla turística Cozumel, México. Investigaciones Turísticas, 18, 138-168. https://doi.org/http://dx.doi.org/10.14198/INTURI2019.18.07

17. Gozgor, G., \& Demir, E. (2018). The Effects of Economic Policy Uncertainty on Outbound Travel Expenditures. Journal of Competitiveness, 10(3), 5-15. https://doi.org/10.7441/joc.2018.03.01

18. Gössling, S., Hall, C. M., y Scott, D. (2015). The Routledge handbook of tourism and sustainability. New York: Routledge.

19. Griffin, T. (2012). Research Note: A Content Analysis of Articles on Visiting Friends and Relatives Tourism, 1990-2010. Journal of Hospitality Marketing y Management, 22(March 2015), 781802. http://doi.org/10.1080/19368623.2012.708960 


\section{JOURNAL OF TOURISM AND SERVICES}

Issue 20, volume 11, ISSN 1804-5650 (Online)

www.jots.cz

20. Gursoy, D., Kim, K., y Uysal, M. (2004). Perceived impacts of festivals and special events by organizers: An extension and validation. Tourism Management, 25(2), 171-181. http://doi.org/10.1016/S0261-5177(03)00092-X

21. Gursoy, D., y Kendall, K. W. (2006). Hosting mega events. Annals of Tourism Research, 33(3), 603623. http://doi.org/10.1016/j.annals.2006.01.005

22. Gursoy, D., y Rutherford, D. G. (2004). Host attitudes toward tourism. Annals of Tourism Research, 31(3), 495-516. http://doi.org/10.1016/j.annals.2003.08.008

23. Harrill, R. (2004). Residents' Attitudes toward Tourism Development: a Literature Review with Implications for Tourism Planning. Journal of Planning Literature, 18(3), 251-266. http://doi.org/10.1177/0885412203260306

24. Havitz, M. E. (2007). A Host, a Guest, and our Lifetime Relationship: Another Hour with Grandma Havitz. Leisure Sciences, 29(2), 131-141. http://doi.org/10.1080/01490400601160754

25. INEGI. (2010). Consulta interactiva de datos. Retrieved August 27th, 2017, from www3.inegi.org.mx

26. Jackson, L. A. (2008). Residents' perceptions of the impacts of special event tourism. Journal of Place Management and Development, 1(3), 240-255. http://doi.org/10.1108/17538330810911244

27. Jackson, R. T. (1990). VFR tourism: is it underestimated? Journal of Tourism Studies, 1(2), 10-17.

28. Jani, D. (2018). Residents' perception of tourism impacts in Kilimanjaro: An integration of the social exchange theory. Tourism: An International Interdisciplinary Journal, 66(2), 148-160.

29. Jorgensen, T. D., Pornprasertmanit, S., Schoemann, A. M., \& Rosseel, Y. (2019). semTools: Useful tools for structural equation modeling. $\mathrm{R}$ package version 0.5-2. Retrieved from https://CRAN.Rproject.org/package $=$ semTools

30. Kaplanidou, K., Karadakis, K., Gibson, H., Thapa, B., Walker, M., Geldenhuys, S., y Coetzee, W. (2013). Quality of Life, Event Impacts, and Mega-Event Support among South African Residents before and after the 2010 FIFA World Cup. Journal of Travel Research, 52(3). http://doi.org/10.1177/0047287513478501

31. Kim, H. J., Gursoy, D., y Lee, S.-B. B. (2006). The impact of the 2002 World Cup on South Korea: Comparisons of pre- and post-games. Tourism Management, 27(1), 86-96. http://doi.org/10.1016/j.tourman.2004.07.010

32. Kim, K. (2002). The effects of tourism impacts upon quality of life of residents in the community. Tesis doctoral. Virginia Polytechnic Institute and State University.

33. Kim, K., Uysal, M., y Sirgy, M. J. (2013). How does tourism in a community impact the quality of life of community residents? Tourism Management, 36, 527-540. http://doi.org/10.1016/j.tourman.2012.09.005

34. Kim, W., Jun, H. M., Walker, M., y Drane, D. (2015). Evaluating the perceived social impacts of hosting large-scale sport tourism events: SCALE development and validation. Tourism

Management, 48, 21-32.

http://doi.org/10.1016/j.tourman.2014.10.015

35. Land, K., Michalos, A., y Sirgy, M. (2011). Handbook of social indicators and quality of life research. Nueva York: Springer \& Business Media.

36. Larsen, J., Urry, J., y Axhausen, K. W. (2007). Networks and tourism. Annals of Tourism Research, 34(1), 244-262. http://doi.org/10.1016/j.annals.2006.08.002

37. Liang, Z. X., y Hui, T. K. (2016). Residents' quality of life and attitudes toward tourism development in China. Tourism Management, 57, 56-67. https://doi.org/10.1016/j.tourman.2016.05.001

38. Macbeth, J., Carson, D., y Northcote, J. (2004). Social Capital, Tourism and Regional Development: SPCC as a Basis for Innovation and Sustainability. Current Issues in Tourism, 7(6), 502-522. http:// doi.org/10.1080/1368350050408668200 


\section{JOURNAL OF TOURISM AND SERVICES}

Issue 20, volume 11, ISSN 1804-5650 (Online)

www.jots.cz

39. Marušić, Z., Horak, S., \& Tomljenović, R. (2008). The Socioeconomic Impacts of Cruise Tourism: A Case Study of Croatian Destinations. Tourism in Marine Environments, 5(2), 131-144. https://doi.org/10.3727/154427308787716767

40. Nováková, B., \& Šoltés, V. (2016). Quality of Life Research: Material Living Conditions in the Visegrad Group Countries. Economics \& Sociology, 9(1), 282-294. https://doi.org/10.14254/2071789X.2016/9-1/19

41. Nowak, P. (2018). Regional variety in quality of life in Poland. Oeconomia Copernicana, 9(3), 381401. https://doi.org/10.24136/oc.2018.019

42. Nunkoo, R., y Gursoy, D. (2012). Residents' support for tourism. Annals of Tourism Research, 39(1), 243-268. http://doi.org/10.1016/j.annals.2011.05.006

43. Organización Mundial del Turismo. (2016). Panorama OMT del turismo internacional. Annual Report, 12. http://doi.org/10.18111/9789284416875

44. Organización para la Cooperación y el Desarrollo Económicos (OCDE). (2017). Estudios Económicos de la OCDE: México. Enero.

45. O'Brien, C. (2008). Sustainable happiness: How happiness studies can contribute to a more sustainable future. Canadian Psychology/Psychologie Canadienne, 49(4), 289-295. http://doi.org/10.1037/a0013235

46. Perdue, R., Long, P., \& Allen, L. (1990). Resident support for tourism development. Annals of Tourism Research, 17(4), 586-599.

47. R Core Team. (2018). R: A language and environment for statistical computing. Vienna, Austria, Austria: R Foundation for Statistical Computing. Retrieved from https://www.r-project.org/

48. Rakauskiené, O. G., \& Volodzkiené, L. (2017). The Inequality of Material Living Conditions in EU Countries. Economics \& Sociology, 10(1), 265-278. https://doi.org/10.14254/2071789X.2017/10-1/19

49. Ranasinghe, R., Pradeepamali, J. (2019). Community Empowerment and their Support for Tourism Development: An Inquiry based on Resident Empowerment through Tourism Scale. Journal of Tourism and Services, 10(19): 55-76. https://doi.org/10.29036/jots.v10i19.96

50. Rosseel, Y. (2012). lavaan: An R Package for Structural Equation Modeling. Journal of Statistical Software, 48(2), 1-36. Retrieved from http://www.jstatsoft.org/v48/i02/

51. Royle, S. A. (2009). Tourism Changes on a Mediterranean Island: Experiences from Mallorca. Island Studies Journal, 4(2), 225-240.

52. Secretaria de Turismo. (2013). El turismo en Mexico 2012. México: Secretaría de Turismo.

53. Secretaría de Turismo. (2013). El turismo de internación en México 2012. México: Secretaría de Turismo.

54. SEDETUR. (2015). Indicadores turísticos enero-diciembre 2014. Chetumal: Secretaría de Desarrollo Turístico de Quintana Roo.

55. Seidl, A., Guillano, F., y Pratt, L. (2006). Cruise tourism and community economic development in Central America and the Caribbean: The case of Costa Rica. Pasos, 4(2), 213-224.

56. Shani, A., y Uriely, N. (2012). VFR tourism. Annals of Tourism Research, 39(1), 421-440. http://doi.org/10.1016/j.annals.2011.07.003

57. Sharpley, R. (2014). Host perceptions of tourism: A review of the research. Tourism Management, 42, 37-49. http://doi.org/10.1016/j.tourman.2013.10.007

58. Sirgy, M. J., Rahtz, D. R., Cicic, M. \& Underwood, R. (2000). A method for assessing residents' satisfaction with community-based services: a quality-of-life perspective. Social Indicator Research, 49(3), 279-316.

59. Sirgy, M. J., y Cornwell, T. (2001). Further validation of the Sirgy et al.'s measure of community quality of life. Social Indicators Research, 56(2), 125-143.

60. Sosa, A. P., Martínez, C., Moncada, P., Beltrán, M., y Álvarez, V. (2015). Visita de familiares y amigos en Cancún: impactos en una comunidad en construcción. In M. N. Andreu, B. Campos, 


\section{JOURNAL OF TOURISM AND SERVICES}

Issue 20, volume 11, ISSN 1804-5650 (Online)

www.jots.cz

y A. P. Sosa (Eds.), Temas pendientes y nuevas oportunidades en turismo y cooperación al desarrollo (pp. 156 166). Playa del Carmen: COODTUR.

61. Tovmasyan, G. (2020). Evaluating the quality of hotel services based on tourists' perceptions and expectations: The case study of Armenia. Journal of International Studies, 13(1), 93-107. https://doi.org/10.14254/2071-8330.2020/13-1/6

62. Uysal, M., Perdue, R. R., \& Sirgy, M. J. (2012). Handbook of tourism and quality-of-life research: enhancing the lives of tourists and residents of host communities. New York: Springer. https://doi.org/10.1007/97894-007-2288-0

63. Vergara, J. C., \& Maza, F. J. (2018). Structural Equation Models Applied for Evaluating Service Quality and Satisfaction in the Healthcare System of Cartagena de Indias D. T. y C. (Colombia). Economics \& Sociology, 11(2), 200-215. https://doi.org/10.14254/2071-789X.2018/11-2/14

64. Woo, E., Kim, H., y Uysal, M. (2015). Life satisfaction and support for tourism development. Annals of Tourism Research, 50, 84-97. https://doi.org/10.1016/j.annals.2014.11.001

65. Woo, E., Uysal, M., y Sirgy, M. J. (2016). Tourism Impact and Stakeholders' Quality of Life. Journal of Hospitality and Tourism Research, 42(2), 260-286. https://doi.org/10.1177/1096348016654971

66. Yolal, M., Gursoy, D., Uysal, M., Kim, H., y Karacaoğlu, S. (2016). Impacts of festivals and events on residents' well-being. Annals of Tourism Research, 61, 1-18. http://doi.org/10.1016/j.annals.2016.07.008

67. Yu, C. P., Cole, S. T., y Chancellor, C. (2016). Assessing Community Quality of Life in the Context of Tourism Development. Applied Research in Quality of Life, 11(1), 147-162. https://doi.org/10.1007/s11482-014-9359-6

68. Ziakas, V., y Costa, C. A. (2010). "Between Theatre and Sport" in a Rural Event: Evolving Unity and Community Development from the Inside-Out. Journal of Sport $y$ Tourism, 15(1), 7-26. http://doi.org/10.1080/14775081003770892

\section{Brief description of Authors:}

\section{Dr. Alfonso González Damián}

Departmento de Estudios Sociales y Empresariales, División de Desarrollo Sustentable, University of Quintana Roo, Cozumel, México, gonzalezd@uqroo.edu.mx. Professor. His main field of research is Sociology of Tourism and is interested in the Tourism Experience Social Construction and Social Sustainability of Tourism Destinations.

\section{M.Sc. Alma Rosa Macías Ramírez}

Departmento de Estudios Sociales y Empresariales, División de Desarrollo Sustentable, University of Quintana Roo, Cozumel, México, maciasalma@uqroo.edu.mx. Professor. Her main field of research is Tourism Marketing and is interested in the Tourism Experience Social Construction and Tourism Destination Image. 